\title{
IMPLEMENTASI ALGORITMA DYNAMIC PROGRAMMING PADA APLIKASI PERHITUNGAN BIAYA PRODUKSI PRODUK PERCETAKAN DENGAN MENGGUNAKAN VISUAL BASIC (STUDI KASUS : CV. BRIZKY ADVERTISING)
}

\author{
A.T.Manurung1 ${ }^{1}$, I.W.Sudarsana ${ }^{2}$, dan A.Sahari ${ }^{3}$ \\ 1,2,3 Program Studi Matematika Jurusan Matematika FMIPA Universitas Tadulako Jalan \\ Soekarno Hatta Km. 09 Tondo, Palu 94118, Indonesia \\ 1'manurunganna@gmail.com,2sudarsanaiwayan@yahoo.co.id, ${ }^{3}$ agus_sh@yahoo.com
}

\begin{abstract}
CV printing Brizky Advertising in running its business activities require registration, sales, predictions and printing better transaction report without wasting much time. If all that is done with the manual will take a very long time and is very detrimental. Then the manual system can be replaced with a computerized system. For example, in the prediction of materials that will be used in the next month as well as input and output material is there, then the problem to determine how much more material that will be used on subsequent sales could be solved properly and appropriately, such as determination of raw materials in april 2016 by simply entering data the results of sales in January, February, March in a program that is already implemented for in CV Brizky Advertising so quickly we can know that in April 2016 CV. Brizky Advertising just need 2 roll to run its business activities in the month. Visual Basic 6 program is built with consideration can be used by officers on a printing press in the bar data, sales data, a data supplier, predicts to be raw materials at Brizky printing advertising. With the attachment of the main menu, input and output are nice will make it easier for officers to do activities with the use of programs that have been built.
\end{abstract}

Keywords : Prediction, Printing, Visual basic 6

\section{ABSTRAK}

Percetakan CV. Brizky Advertising dalam menjalankan aktivitas bisnisnya membutuhkan pencatatan, penjualan, prediksi dan percetakan laporan transaksi yang lebih baik tanpa membuang waktu banyak. Jika semua itu dilakukan dengan manual akan memakan waktu yang sangat lama dan sangat merugikan. Maka sistem manual tersebut dapat diganti dengan system komputerisasi. Misalnya pada Prediksi bahan yang akan digunakan pada bulan berikutnya serta input dan output bahan yang ada, maka masalah untuk menentukan berapa banyak bahan lagi yang akan digunakan pada penjualan berikutnya dapat dipecahkan dengan baik dan tepat, seperti penentuan bahan baku pada bulan april 2016 hanya dengan memasukkan data hasil penjualan pada bulan Januari, Februari, Maret pada program yang sudah di implementasikan untuk CV. Brizky Advertising maka dengan cepat kita dapat mengetahui bahwa pada bulan April 2016 CV. Brizky Advertising hanya membutuhkan 2 roll untuk menjalankan 
aktivitas bisnisnya di bulan tersebut. Program Visual Basic 6 ini dibangun dengan pertimbangan dapat digunakan oleh petugas pada percetakan dalam penginput data barang, data penjualan, data supplier, hingga dapat memprediksi bahan baku pada percetakan Brizky advertising tersebut. Dengan lampiran menu utama, input serta output yang bagus akan memudahkan petugas untuk melakukan aktivitas dengan menggunakan program yang telah dibangun.

Kata Kunci : Prediksi, Percetakan, Visual Basic 6.

\section{PENDAHULUAN}

\subsection{Latar Belakang}

Kemajuan teknologi pada saat ini yang berkembang dengan sangat pesat, khususnya dalam bidang kom puter. Teknologi informasi membuat kom puter bukan merupakan hal yang asing lagi bagi manusia melainkan sudah dijadikan suatu fasilitas yang dapat membantu atau mempermudah segala bentuk kebutuhan manusia akan informasi dan teknologi. Kemampuan komputer untuk mengolah informasi saat ini sudah tidak dapat diragukan lagi, hal ini terlihat dengan banyaknya aplikasi yang dibuat untuk membantu suatu perusahaan. Pada setiap perusahaan membutuhkan sistem pengolahan data khusus untuk mengelola suatu data dengan cepat dan tepat sehingga tidak terlalu banyak menyita waktu dan tenaga dalam meyelesaikan suatu pekerjaan terutama pada bagian administrasi.

CV. Brizky Advertising merupakan salah satu perusahaan yang bergerak di bidang percetakan. Layaknya sebuah perusahaan pada umumnya, kepuasan pelanggan sangat dikedepankan terutama masalah harga.

\subsection{Rumusan Masalah}

Bagaimana merancang sebuah aplikasi yang dapat melakukan prediksi perhitungan penentuan bahan baku yang digunakan sehingga dapat menghitung biaya produksi produk percetakan dengan perangkat computer

\subsection{Tujuan}

Penelitian ini bertujuan untuk:

1. Mendapatkan sebuah aplikasi berbasis computer khususnya untuk Menghitung biaya produk percetakan pada CV. Brizky Advertising

2. Mendapatkan prediksi perhitungan bahan baku yang akan digunakan oleh CV. Brizky Advertising 


\section{METODE PENELITIAN}

\subsection{Lokasi Penelitian}

Pada teknik observasi ini, penulis mempelajari secara langsung proses perhitungan biaya produksi di CV. Brizky Advertising, hal ini dilakukan untukmemahamidanmendapatkan informasi jelas seputar proses perhitungan bahan baku secara khusus maupun perhitungan biaya produksi secara umum.

\subsection{Metode Pengembangan Sistem}

Dalam penelitian ini metode pengembangan sistem yang digunakan adalah Rapid Application Development (RAD). RAD adalah sebuah model proses pengem banganperangkat lunak sekuensial linear yang menekankan siklus pengembangan cepat. Model RAD ini merupakan adaptasi "kecepatan tinggi" dari model sekuensial linear di mana pengembangan cepat dicapai dengan menggunakan model pendekatan konstruksi berbasis komponen. Jika kebutuhan dipahami dengan baik, proses RAD memungkinkan tim pengembang menciptakan "sistem fungsional yang utuh" dalam periode waktu periode yang sangat pendek kira-kira 6090 hari. (Pressman,2010:82).

Model RAD digunakan dengan tujuan mempersingkat waktu penge rjaan aplikasi serta proses yang dihasilkan, didapatkan secara cepat dan tepat, ilustrasi model RAD seperti berikut

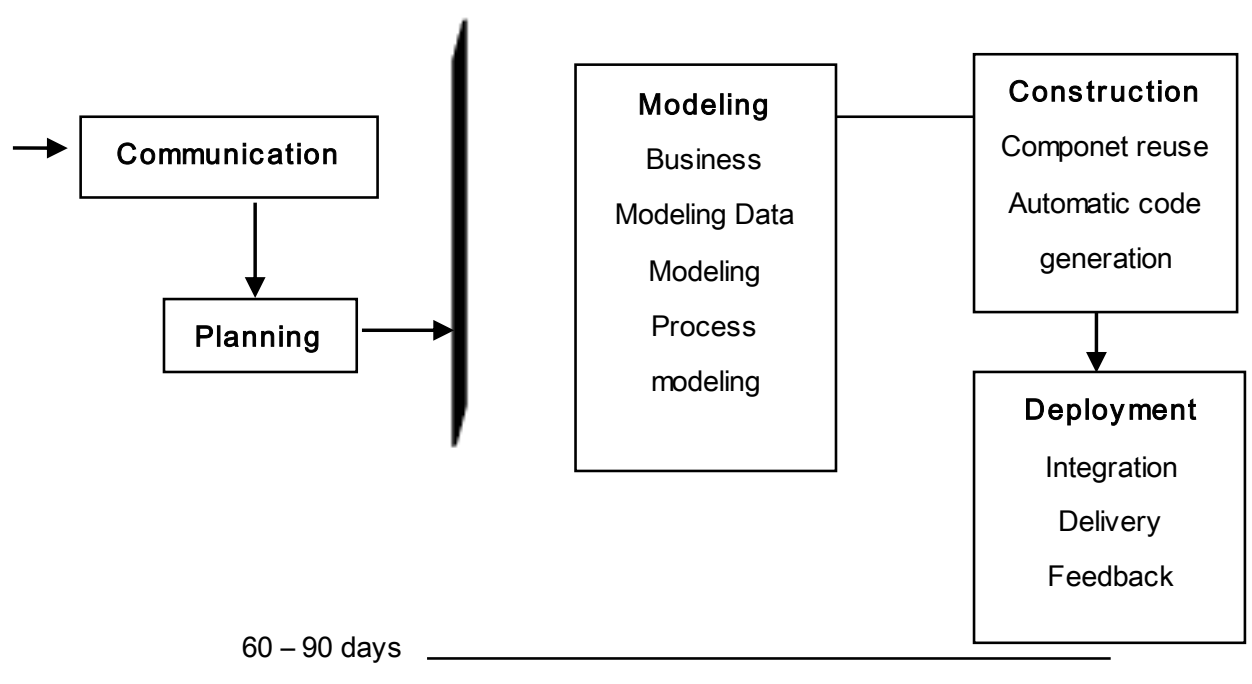

Gambar 1 : Model RAD 


\section{HASIL DAN PEMBAHASAN}

\subsection{Hasil}

Hasil dari penelitian ini merupakan sebuah aplikasi yang dapat digunakan untuk menentukan jumlah produksi dan prediksi bahan baku yang akan di gunakan oleh Cv. Brizky Advertising

\subsubsection{Menghitung Jumlah Bahan Baku}

Sebelum menentukan rata-rata dan prediksi maka terlebih dahulu menghitung jumlah permintaan konsumen dan jumlah bahan baku yang keluar dari setiap bulan berjalan yang bertujuan untuk mengetahui berapa banyak bahan yang digunakan di tiap bulan berjalan dengan rumus :

$\mathrm{V} \times \mathrm{W}=\mathrm{Z}$

Dimana :

$v=$ Ukuran permintaan

$\mathrm{w}=$ Jumlah pesanan

z = Jumlah bahan yang keluar

Tabel 1 : Ukuran dan Jumlah Pesanan pada bulan Januari 2016

\begin{tabular}{|c|c|}
\hline Ukuran & Jumlah Pesanan \\
\hline $0.30 \times 0.80$ & 1 \\
\hline $0.40 \times 0.60$ & 3 \\
\hline $0.50 \times 1$ & 1 \\
\hline $0.60 \times 0.80$ & 3 \\
\hline $0.60 \times 1.60$ & 3 \\
\hline $0.75 \times 0.50$ & 1 \\
\hline $1 \times 0.5$ & 3 \\
\hline $1 \times 0.50$ & 8 \\
\hline $1 \times 0.60$ & 5 \\
\hline $1 \times 0.75$ & 2 \\
\hline $1 \times 1$ & 14 \\
\hline $1 \times 1.36$ & 24 \\
\hline $1 \times 2.5$ & 1 \\
\hline $1.15 \times 0.75$ & 3 \\
\hline $1.20 \times 0.75$ & 1 \\
\hline $1.25 \times 0.60$ & 1 \\
\hline $1.40 \times 0.70$ & 1 \\
\hline $1.5 \times 0.50$ & 3 \\
\hline $1.5 \times 0.90$ & 2 \\
\hline
\end{tabular}




\begin{tabular}{|c|c|}
\hline $1.5 \times 1$ & 6 \\
\hline $1.60 \times 0.60$ & 4 \\
\hline $2 \times 0.30$ & 2 \\
\hline $2 \times 0.80$ & 1 \\
\hline $2 \times 1$ & 13 \\
\hline $2 \times 3$ & 2 \\
\hline $2.20 \times 0.80$ & 2 \\
\hline $2.44 \times 1.22$ & 1 \\
\hline $2.50 \times 0.80$ & 2 \\
\hline $2.50 \times 1$ & 1 \\
\hline $3 \times 0.30$ & 1 \\
\hline $3 \times 1$ & 22 \\
\hline $3 \times 1.5$ & 1 \\
\hline $3 \times 2$ & 3 \\
\hline $3 \times 4$ & 13 \\
\hline $3.5 \times 1$ & 2 \\
\hline $3.50 \times 3$ & 1 \\
\hline $4 \times 1$ & 2 \\
\hline $4 \times 2.5$ & 1 \\
\hline $4.90 \times 2$ & 1 \\
\hline $5 \times 1$ & 4 \\
\hline $8 \times 1.50$ & 2 \\
\hline
\end{tabular}

Dari tabel diperoleh jumlah pesanan pada bulan januari sebanyak 167 dan banyaknya bahan baku yang keluar sebanyak 476,8 meter.

\subsubsection{Metode Rata-rata (Moving average)}

Metode ini beranggapan bahwa setiap terjadinya perubahan jumlah persediaan bahan baku, baik karena pembelian maupun karena adanya penjualan yang dilakukan oleh perusahaan, sisa persediaan bahan baku yang masih ada segera dihitung rata-ratanya. Dengan metode inilah kita dapat memprediksikan berapa banyak bahan baku yang akan dibutuhkan pada bulan berikutnya dengan mengambil rata-rata penjualan pada tiga bulan sebelumnya agar hasil lebih tepat, yaitu ;

$$
\begin{aligned}
& \mathrm{N}=\frac{\text { Penjualan selama } 3 \text { bulan }- \text { jumlah stok yang tersisa }}{3 \text { bulan }} \\
& \mathrm{N}=\mathrm{w} / \mathrm{3} \text { (rata-rata) } \ldots \ldots \ldots \ldots \ldots \ldots \ldots \ldots \ldots \ldots \ldots \ldots \ldots \ldots \ldots \ldots \ldots \ldots \ldots \ldots \ldots \ldots \ldots \ldots \ldots \ldots \ldots \ldots
\end{aligned}
$$

$\mathrm{N}=\frac{(476.2+727.7+490.2)-73.04407}{3}$ 
$\mathrm{N}=\frac{1694.1-73.04407}{3}$

$\mathrm{N}=\frac{1621.0559}{3}$

$\mathrm{N}=540.35197 \mathrm{~m} / 2$ Roll

Dimana: $a=$ Jumlah Penjualan bulan 1

$\mathrm{b}=$ Jumlah penjualan bulan 2

$c=$ Jumlah penjualan bulan 3

$\mathrm{s}=$ Jumlah stok bahan yang masih ada

$w=$ Hasil sementara jum lah penjualan selama 3 bulan dikurangi jumlah stok yangada

$\mathrm{N}=$ Hasil prediksi bahan baku

Ket : 1 Roll $=<560$ meter

3 Roll $=>560$ meter

\subsection{Form Prediksi}

Ini merupakan perancangan Interface untuk memprediksi bahan baku yang akan digunakan oleh CV. Brizky Advertising pada bulan berikutnya. Pada form prediksi terdapat beberapa tombol yang harus diisi untuk mengetahuii prediksi bahan baku yang akandigunakan yaitu kode barang, nama barang, harga, bulan, tahun. Tombol Prediksi untuk mengetahui prediksi pada bulan selanjutnya.

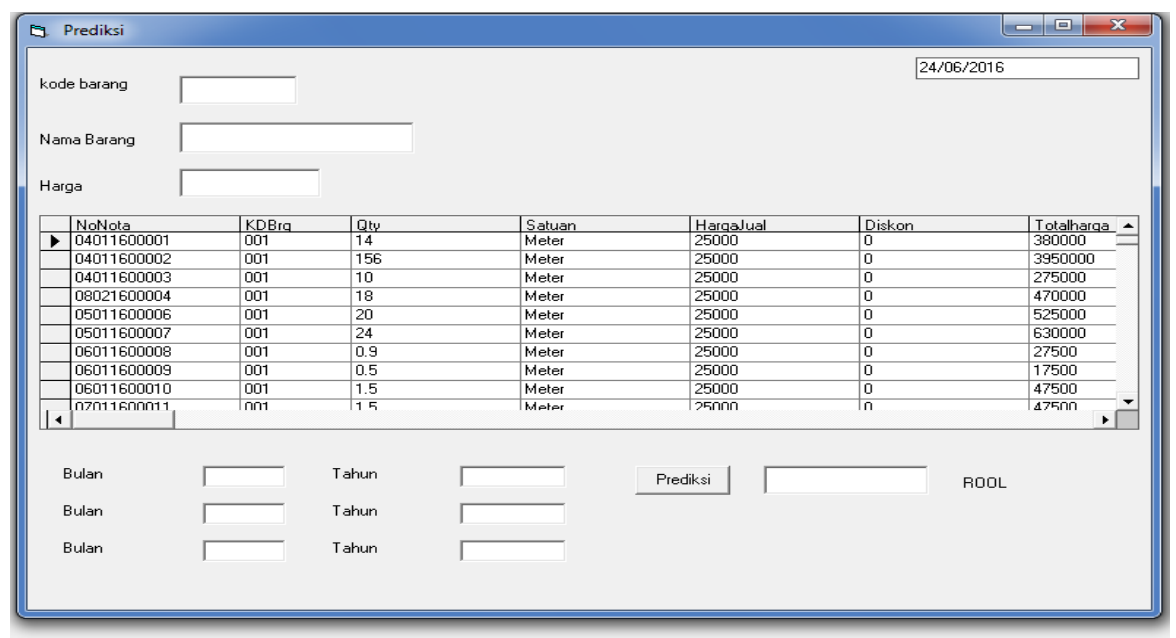

Gambar 2 : Form Prediksi 


\section{KESIMPULAN}

Berdasarkan hasil penelitian dan pembahasan yang diperoleh, dapat diambil beberapa kesimpulan sebagai berikut:

1. Berdasarkan hasil penerapan aplikasi pada Cv. Brizky Advertizing, aplikasi yang dihasilkan dapat membantu mengolah data penjualan produk pada Cv. Brizky Advertising secara lebih cepat, akurat, dan memiliki efisiensi waktu.

2. Untuk proses penjualan produk, aplikasi yang diim plementasikan pada Cv. Brizky Advertising berhasil mengolah data dan berhasil memprediksikan bahwa bahan yang akan digunakanoleh Cv. Brizky Advertising pada bulan April 2016 sebanyak 2 roll.

\section{DAFTAR PUSTAKA}

[1] Kadir, Abdul dan Heriyanto, Algoritma Pemograman Menggunakan C++, 2005, CV Andi Offset, Yogyakarta.

[2] Kamus Besar Bahasa Indonesia

[3] Lew, A dan Mauch, H, Dynamic Programming A Computational Tool, 2007, Berlin: Springer.

[4] Pressman, Roger S, Software Engineering"A Practitioner's Approach", 2010, New York: McGraw Hill.

[5] Sismoro, Logika informatika, Algoritma dan Pemograman Komputer, 2005, Jogyakarta: Jogyakarta. 